\title{
RETHINKING PENGELOLAAN PESANTREN DI INDONESIA
}

\author{
Afga Sidiq Rifai \\ Dosen Tetap Porgram Studi Pendidikan Agama Islam Fakultas Agama Islam \\ Universitas Muhammadiyah Magelang
}

\begin{abstract}
Boarding schools as institutions that are non-formal education must change and renewal of generations to produce a strong, knowledgeable generation with soul force boarding and determination to develop knowledge that remain rooted in the Qur'an and Hadith. In the times, boarding is now faced with globalization and modernization are marked by the rapid pace of information and technology. "Therefore, boarding schools have to change the format, shape, orientation and education methods with a note not to change the vision, mission and orientation of the boarding school, but the change is only on the outward side, while on the inside is still maintained.
\end{abstract}

\section{Keywords: Updates, Boarding school, Barriers}

\begin{abstract}
Abstrak
Pesantren sebagai lembaga pendidikan yang bersifat nonformal harus mengadakan perubahan dan pembaharuan guna menghasilkan generasi-generasi yang tangguh, generasi yang berpengetabuan luas dengan kekuatan jiwwa pesantren dan keteguhan mengembangkan pengetabuan yang tetap bersumber pada al-qur'an dan hadis. Dalam perkembangan zaman, pesantren saat ini berhadapan dengan arus globalisasi dan modernisasi yang ditandai dengan cepatnya laju informasi dan teknologi. "Karena itu, pesantren harus melakukan perubahan format, bentuk, orientasi dan metode pendidikan dengan catatan tidak sampai merubah visi, misi dan orientasi pesantren itu, akan tetapi perubaban tersebut hanya pada sisi luarnya saja, sementara pada sisi dalam masib tetap dipertahankan.
\end{abstract}

\section{Kata Kunci: Pembaharuan, Pesantren, Hambatan}

\section{PENDAHULUAN}

Pendidikan Islam pada dasarnya adalah pendidikan yang bertujuan untuk membentuk pribadi muslim seutuhnya, mengembangkan seluruh potensi manusia baik yang berbentuk jasmani maupun rohani ${ }^{1}$. Pendidikan Islam disebut juga sebagai sistem dan cara meningkatkan kualitas hidup manusia ${ }^{2}$. Pengertian pendidikan dengan seluruh totalitasnya dalam konteks Islam inheren dengan istilah "tarbiyah, ta'lim, dan ta'dib" yang harus dipahami secara bersamasama. Ketiga istilah ini mengandung makna yang

${ }^{1}$ Haidar Putra Daulay, Pendidikan Islam Dalam Sistem Pendidikan Nasional Di Indonesia (Jakarta:Prenada Media, 2004) hal. 31

${ }^{2}$ Hujair, AH Sanaky, Paradigma Pendidikan Islam Membangun Masyarakat Madani Indonesia (Yogyakarta: Safiria Insania Press, 2003) hal.4 mendalam menyangkut manusia dan masyarakat serta lingkungan yang dalam hubungannya dengan Tuhan saling berkaitan satu sama lain. Istilah-istilah itu pula sekaligus menjelaskan ruang lingkup pendidikan Islam: informal, formal dan non formal.

Pesantern sebagai pendidikan nonformal adalah sebuah lembaga pendidikan dan penyiaran agama Islam ${ }^{3}$. Pondok pesantren juga sebagai basis pendidikan yang tertua di Indonesia karena sejalan dengan perjalanan penyebaran Islam di Indonesia, hal ini dibuktikan dengan telah berdirinya pondok-pondok pesantren sejak abad ke-15, seperti Pesantren Gelogah Arum yang didirikan oleh Raden Fatah pada tahun 1476 sampai pada abad ke-19 dengan beberapa

${ }^{3}$ Dawam Rahardjo, Pergulatan Dunia Pesantren Dari Bawab (Jakarta: P3M, 1985)

102 
pondok-pondok pesantren yang dipimpin oleh para wali, seperti Pesantren Sunan Malik Ibrahim di Gresik, Pesantren Sunan Bonang di Tuban, Pesantren Sunan Ampel di Surabaya dan Pesantren Tegal Sari yang terkemuka di Jawa ${ }^{4}$.

Eksistensi pondok pesantren dalam menyikapi perkembangan zaman, tentunya memiliki komitmen untuk tetap menyuguhkan pola pendidikan yang mampu melahirkan SDM yang handal. Adapun yang melatar belakangi penyusun untuk menyusun makalah ini adalah minimnya pengetahuan penyusun tentang pembaharuan apa saja yang seharusnya dilakukan di pesantren dalam menghadapi tantangan dan hambatan di masa modern, adapun salah satu tujuan dari penyusunan makalah ini adalah untuk menambah pengetahuan tentang dunia pendidikan pesantren.

\section{PEMBAHASAN}

\section{Potret Pendidikan Pesantren}

Pesantren yang diakui sebagai model pendidikan awal (Islam) di Indonesia sampai saat ini masih eksis dan diakui keberadaannya di masayarakat, meskipun tidak jarang di antara masyarakat membcarakan pengelolaan pendidikan pesantren yang masih kurang.

Pengelolaan pesantren yang apa adanya tersebut mudah dilihat dari kurikulum sebagai pesantren yang belum dikembangkan dan disesuaikan dengan perkembangan ilmu dan teknologi. Sebagai akibatnya, para alumni pesantren juga sering kali gagap dalam menghadapi tantangan zaman. Sebagai contoh, tatkala ada sebagian alumni pesantren yang menjadi tokoh masyarakat sebaga politisi, mereka seakan gagap menghadapi perannya yang baru karena mereka memang belum atau bahkan tidak mengetahui betul bagaimana "konstruksi polotik Islam" dan strategi berpolitik yang disebut-sebut sebagai high politic. Hal tersebut terjadi karena materi kajian yang diberikan di pesantren kurang dikontekstualkan dengan perkembangan zaman seperti fih politik/fiqh as-siyasab belum diberikan secara baik dan terstrukturkan dalam bangunan kurikulum pesantren ${ }^{5}$.

${ }^{4}$ Roihan dalam Amirudin Nahrawi, Pembaharuan Pendidikan Pesantren (Yogyakarta: Gama Media, 2008) hal. 1 ${ }^{5}$ Moh. Roqib, Ilmu Pendidikan Islam (Yogyakarta:
Bukti pengelolaan pesantren yang apa adanya adalah tenaga pengajar pesantren yang belum dipersiapkan secra sistematis sebgai ustadz profesional yang menguasai maddah dan sekaligus mampu mempraktikan metode (thariqab) pembelajaran yang baik. Hal lain yang membuktikan lemahnya pengelolaan pesantren adalah jaringan sebagian pesantren juga diakui lemah, baik jaringan dengan sesama pesantren, masyarakat, pengusaha, maupun pemerintah. komunikasi yang dilakukan pesantren kurang intensif dan efektif. Hal lain yang bisa dijadikan bukti adalah rendahnya pengelolaan pembelajaran di pesantren bisa dilihat dari terbatasnya sarana dan prasarana yang dimilikinya. Padahal jika pesantren mampu meyakinkan stake holder bahwa ia mampu menyiapkan santri yang berkualitas maka pesantren tersebut akan mudah membangun jaringan yang kuat, yang memungkinkan kebutuhannya akan sarana dan prasarana terpenuhi dengan baik. Hal ini sudah terbukti di beberapa pesantren yang telah maju dan besar sehingga mereka mampu menggalang dukungan dana dari masyarakat melalui waqaf dan lainnya ${ }^{6}$.

Meski banyak kelemahan yang dimiliki oleh pesantren, sebagian besar di antaranya masih tetap mendapatkan tempat di hati masyarakat muslim Indonesia, Terlebih lagi pesantren yang memiliki figur kharismatik, mampu menjaga kualitas keilmuannya, berkonsentrasi penuh terhadap perkembangan keilmuannya para santri, dan mampu membangun komunikasi yang baik dengan komunitas sosial dan pemerintah ${ }^{7}$.

\section{Pengertian Pembaharuan Pendidikan Islam}

Secara bahasa, kata tajdid berarti pembaharuan. Dalam bahasa Arab, sesuatu dikatakan "jadid" (baru), jika bagian-bagiannya masih erat menyatu dan masih jelas. Maka upaya tajdid seharusnya adalah upaya untuk mengembalikan keutuhan dan kemurnian Islam kembali. Dalam hal ini tajdid adalah koreksi ulang atau konseptualisasi ulang pada hakikatnya selalu berorientasi pada pemurnian yang sifatnya kembali

\footnotetext{
LkiS Yogyakarta, 2009) hal. 149

${ }^{6}$ Ibid., hal 150

${ }^{7}$ Ibid., hal 151
} 
pada ajaran asal dan bukan adopsi pemikiran asing, dalam pelaksanaannya diperlukan pemahaman yang dalam akan paradigma dan pandangan hidup islam yang bersumber dari al-quran dan sunnah, serta pendapat para ulama terdahulu yang secara ijma dianggap shahih. Pembaharuan Islam bukanlah sesuatu yang evolusioner, melainkan lebih cenderung devolusioner, dengan artian bahwa pembaharuan bukan merupakan proses perkembangan bertahap di mana yang datang kemudian lebih baik dari sebelumnya ${ }^{8}$.

Harun Nasution menyebut gerakan pembaharuan pemikiran Islam dengan istilah modernisasi pemikiran Islam yang mempunyai arti, seperti dikutip Azyumardi Azra sebagai suatu aliran, gerakan, pemikiran, dan usaha untuk mengubah paham, adat istiadat agar semuanya disesuiakan dengan pendapat dan keadaan baru yang timbul oleh kemajuan ilmu pengetahuan serta teknologi modern. Adapun modernisasi menurut KBBI, adalah suatu proses pergeseran sikap dan mentalitas sebagai warga masyarakat untuk bisa hidup sesuai dengan tuntutan hidup masa kini?.

Berbeda dengan Harun Nasution, Maulana Maududi menyebut pembaruan pemikiran Islam dengan istilah tajaddud-tajdid, istilah tersebut diartikan sebagai suatu gerakan pemurnian yang merupakan reaksi atas melemah dan membekunya karena ancaman dari luar, menurut Maulana Maududi, suatu gerakan bisa disebut sebagai pembaruan jika:

a. Merupakan usaha perbaikan kondisi masyarakat dengan membersihkan penyakit yang meracuninya

b. Mencari letak permasalahan untuk menyelesaikannya

c. Identifikasi kemampuan dirinya untuk melakukan pembaruan

d. Upaya menciptakan perombakan pandangan dan pola berpikir masyarakat ke arah yang lebih baik.

e. Upaya perbaikan secara praksis

${ }^{8}$ Makalah Eka Lusiandani Koncara, Konsep Pembaharuan Dalam Islam (Purwakarta) hal.2s

${ }^{9}$ Abd. Rachman Assegaf, Pendidikan Islam Kontekstual (Yogyakarta: Pustaka Pelajar, 2010) hal. 88 f. Active dan responsive mengembangkan aplikasi Islam

g. Merombak secara Internasional ${ }^{10}$.

Berdasarkan asumsi bahwa pembaruan pendidikan Islam bersumber dari upaya pembaruan pemikiran Islam, maka pembaruan pendidikan Islam diartikan sebagai pembaruan pemikiran yang dilakukan dalam bidang pemikiran maupun praktek pendidikan Islam. Dengan makna ini, pendapat manapun mengenai pembaruan pemikiran dapat disubtitutikan. Gerakan pembaruan pada dasarnya mengusung nilai-nilai seperti: nilai pembaruan, nilai perjuangan, nilai kemerdekaan pikiran agama dan pikiran, nilai persatuan dan solidaritas.

\section{Beberapa Pembaharuan Pesantren}

Pesantren merupakan lembaga pendidikan Islam yang tertua di Indonesia, disinyalir sebagai sistem pendidikan yang lahir dan tumbuh melalui kultur Indonesia yang bersifat "indogenous", yang mana telah mengadopsi model pendidikan sebelumnya yaitu dari pendidikan Hindu dan Budha sebelum kedatangan Islam ${ }^{11}$. Pondok pesantren sebagai lembaga pendidikan Islam memiliki kekhasan, baik dari segi sistem maupun unsur pendidikan yang dimilikinya. perbedaan dari segi sistem, terlihar dari proses belajar mengajar yang cenderung sederhana, meskipun harus diakui ada juga pesantren yang memadukan sistem modern dalam pembelajarannya ${ }^{12}$.

Berdasarkan tujuan pendiriannya, pesantren hadir dilandasi sekurang-kurangnya oleh dua alasan: pertama, pesantren dilahirkan untuk memberikan respon terhadap situasi dan kondisi sosial suatu masyarakat yang tengah pada runtuhnya sendi-sendi moral, melalui transformasi nilai yang ditawarkan (amar ma;ruf, nabyi munkar). Kedua, salah satu tujuan pesantren adalah menyebarluaskan informasi ajaran tentang universalitas Islam ke seluruh plosok nusantara

${ }^{10}$ Ibid., hal.88

${ }^{11}$ Maunah, Tradisi Intelektual Santri Dalam Tantangan Dan Hambatan Pendidikan Pesantren Di Masa Depan (Yogyakarta:Teras, 2009) hal. 1

${ }^{12}$ Amirudin Nahrawi, Pembaharuan Pendidikan Pesantren (Yogyakarta: Gama Media, 2008) hal. 23 
yang berwatak pluralis, baik dalam dimensi kepercayaan, budaya maupun kondisi sosial masyarakat ${ }^{13}$.

Di tengah kompetisi sistem pendidikan yang ada, pesantren sebagai lembaga pendidikan tertua yang masih bertahan hingga kini tentua saja harus sadar bahwa penggiatan diri yang hanya pada wilayah keagamaan tidak lagi memadai, maka dari itu pesantren harus proaktif dalam memberikan ruang bagi pembenahan dan pembaharuan sistem pendidikan pesantren dengan senantiasa harus selalu apresiatif sekaligus selektif dalam menyikapi dan merespon perkembangan dan pragmatisme budaya yang kian menggejala. Hal tersebut dapat dijadikan pertimbangan lain bagaimana seharusnya pesantren mensiasati fenomena tersebut dengan beberapa perubahan pesantren di bawah ini

\section{Pembaharuan Metode pembelajaran}

Model Pembelajaran pesantren pada mulanya populer menggunakan metodik-didaktif dalam bentuk sorogan, bandongan, halaqab dah hafalan. Menurut Mastuhu (1989: 131), pembaharuan metode pembelajaran mulai terjadi sekitar awal abad ke-20 atau tepatnya sekitar tahun 1970-an, dari pola sorogan berubah menjadi sistem klasikal, tidak hanya itu, beberapa pendidikan keterampilan juga mulai masuk ke dunia pesantren, seperti bertani, berternak, kerajinan tangan mulai akrab dikehidupan santri sehari-hari. ini dimaksudkan untuk mengembangkan wawasan atau orientasi santri dari pandangan hidup yang selalu berpandangan ukhrowi, supaya seimbang dengan kehidupan duniawi ${ }^{14}$.

\section{Pembabaruan Kurikulum}

Pada umunya pesantren sebagai lembaga pendidikan Islam, materi pembelajarannya lebih mengutamakan pelajaran agama Islam yang bersumber dari kitab-kitab klasik, seperti tauhid, hadis, tafsir, fiqih dan sejenisnya. Kurikulum didasarkan pada tingkat kemudahan dan kompleksitas kitab-kitab yang dipelajari, mulai dari tingkat awal, menengah dan lanjut ${ }^{15}$.

\footnotetext{
${ }^{13}$ Maunah, Tradisi Intelektual... hal 25-26

${ }^{14}$ Amirudin Nahrawi, Pembaharuan Pendidikan...... hal. 28

${ }^{15}$ Ibid., hal. 28
}

Dalam perkembangannya, hampir setiap pesantren telah melakukan pembaharuan kurikulum dengan memasukkan pendidikan umum dalam kurikulum pesantren. Sifatnya bervariasi, ada pesantren yang memasukan pendidikan 30\% agama dan $70 \%$ umum, adapula yang sebaliknya, yakni $80 \%$ agama dan sisanya pelajaran umum.

\section{Pembaharuan Evaluasi}

Kemampuan santri biasanya dievaluasi dengan keberhasilannya mengajarkan kitab kepada orang lain. Apabila audiensi merasa puas, maka santri yang bersangkutan dinilai telah lulus. Legalisasi kelulusannya adalah restu kiai bahwa santri tersebut diizinkan pindah untuk mempelajari kitab lain yang lebih tinggi tingkatannya dan boleh mengajarkan kitab yang dikuasainya kepada yang lain.

Pesantren yang telah mengadopsi pembaruan kurikulum, baik yang mengacu pada Departemen Agama maupun Departemen Pendidikan Nasional jelas telah meninggalkan model evaluasi tersebut. Model madrasi/ klasikal evaluasinya sebagaimana madrasah pada umunya, yaitu menggunakan ujian resmi dengan memberikan angka-angka kelulusan serta tanda kelulusan seperti ijazah ${ }^{16}$.

\section{Pembaharuan Organisasi/ Manajemen}

Dalam konteks pembaharuan manajemen, meskipun peran kiai tetap dipandang penting, tetapi kiai tidak ditempatkan pada posisi penentu kebijakan secara tunggal. Dari sini kerja dimulai dengan pembagian unit-unit kerja sesuai urutan yang ditetapkan pimpinan pesantren. Ini berarti kekuasan kiai telah terdistrubusi kepada yang lain yang dipercaya untuk mengemban tugas, mekanisme kerja juga mulai diarahkan sesuai dengan visi dan misi pesantren. Berangkat dari hal tersebut, terkadang tetap diakui bahwa pola perencanaan pesantren umunya masih tergolong sederhana, seringkali program jangka pendek, menengah, dan jangka penjang tampak tumpang tindih. Akibatnya, program-programn demikian sulit diukur tingkat pencapainnaya ${ }^{17}$.

\footnotetext{
${ }^{16}$ Ibid., hal. 30

${ }^{17}$ Ibid., hal. 30-31
} 


\section{Prinsip-Prinsip Pembaharuan Pesantren}

Proses globalisasi adalah suatu proses menuju keadaan budaya global yang pasti setuju atau tidak setuju memasuki budaya Indonesia yang pada akhirnya akan mengubah hal-hal yang mendasar dalam pandangan hidup dan mencukupi seluruh aspek kehidupan. Berangkat dari hal tersebut, KH. Ali Maksum menyatakan delapan prinsip-prinsip yang terlihat dan harus diterapkan dalam pemharuan pendidikan pesantren, yaitu ${ }^{18}$ :

a. Memiliki kebijaksanaan menurut ajaran Islam.

Para santri dibantu agar mampu memahami makna hidup, keberadaan, peranana, serta tanggung jawabnya dalam kehidupan di masyarakat.

b. Memiliki kebebasan yang terpimpin. Setiap manusia memiliki kebebasan, tetapi kebebasan itu harus dibatasi karena kebebasan memiliki potensi anarkisme. Keterbatasan (ketidak bebasan) mengandung kecenderungan mematikan kreativitas, berangkat dari hak tersebut, maka pembatasan harus dibatasi. Inilah yang dimaksud kebebasan yang terpimpin, dan kebebasan inilah yang dibentuk oleh K.H. Ali Maksum dalam mengasuh santrinya

c. Berkemampuan mengatur diri sendiri. Pada umumnya santri harus dapat mengatur diri sendiri dan kehidupannya menuruti batasan yang telah diajarkan agama.

d. Memiliki rasa kebersamaan yang tinggi. Dalam hal kewajiban santri harus menunaikan kewajiban terlebih dahulu, sedangkan dalam hak-hak, para santri harus mendahulukan kepentingan orang lain sebelum kepentingan sendiri

e. Menghormati orang tua dan guru. Ini memang ajaran Islam, tujuan ini dicapai antara lain melalui penegakan berbagai pranata di pesantren seperti mencium tangan guru, tidak membantah guru. Demiian juga terhadap orang tua, karena nilai-nilai ini sudah banyak terkikis di sekolah-sekolah.

f. Cinta kepada ilmu. Menurut al-quran ilmu (pengetahuan) datang dari Allah, banyak hadis yang yang mengajarkan pentingnya menuntut

${ }^{18}$ Ibid., hal. 85-87 ilmu dan menjaganya, maka dari itu para santri harus memandang ilmu sebagai sesuatu yang suci dan tinggi.

g. Mandiri. Apabila mengatur diri sendiri kita sebut otonomi, maka mandiri yang dimaksud adalah berdiri atas kekuasaan sendiri, sejak awal santri telah dilatih untuk mandiri, sperti kebanyakan masak sendiri, mengatur uang belanja sendiri, mencuci pakaian sendiri dan sebagainya.

h. Kesederhanaan. Dilihat secara lahiriah sederhana memang mirip dengan kemiskinan, padahal yang dimaksud sederhana contohnya di Pesantrern Krapyak adalah sikap hidup, yaitu sikap memandang sesuatu, terutama materi secara wajar, proporsional dan fungsional. Sebenarnya banyak para santri yang berlatar belakang orang kaya, mereka dilatih hidup sederhana. Ternyata orang kaya tidak sulit menjalani kehidupan sederhana bila dilatih seperti di kehidupan pesantren, apa yang melatih mereka? kondisi pesantren itulah yang melatih mereka. Di sini kita melihat bahwa pesantren adalah suatu sistem; yang kondisi itu merupakan salah satu elemennya. kesederhanaan itu sesungguhnya realisasi keimanan dari ajaran Islam yang pada umunya telah diajarkan para sufi. Hidup secara sufi memang merupakan suatu yang khas pada umumnya.

\section{Tantangan dan Hambatan Pendidikan Pesantren Di Era Modernitas}

Pondok pesantren Islam sebetulnya banyak berperan mendidik sebagian bangsa Indonesia sebelum lahirnya lembaga-lembaga pendidikan lain yang cenderung mengikuti pola 'Barat' yang modern, maka dari itu, lembaga pendidikan pesantren sering dijuluki sebagai basis pendidikan tradisional yang khas Indonesia.

Tantangan dan harapan masyarakat akan adanya suatu pesantren yang berkualitas semakin marak. Pesantren diharapkan memberi sesuatu dan mereflesikan kebutuhan konsumen, namun harapan ini tidak mudah direalisasikan dengan cepat karena peningkatan mutu pesantren lebih merupakan proses daripada hanya kejadian seketika. Sebagai pendidikan alternatif, tantangan 
yang dihadapi pesantren semakin hari semakin besar, kompleks dan mendesak, sebagai akibat meningkatnya kebutuhan pembangunan dan kemajuan ilmu pengetahuan dan teknologi. Sementara itu, perkembangan fisik bangunan pesantren juga mengalami kemajuan-kemajuan yang sangat observable, banyak pesantren di berbagai tempat, apakah wilayah urban, maupun pedesaan mempunyai gedung atau bangunan yang megah dan dan lebih penting lagi, sehat dan kondusif sebagai tempat berlangsungnya proses pendidikan yang baik. dengan demikian, citra yang pernah disandang pesantren sebagai kompleks bangunan yeng reot dan tidak higienis semakin memudar ${ }^{19}$.

Tantangan di atas menyebabkan terjadinya pergeseran nilai-nilai di pesantren baik nilai yang menyangkut pengelolaan pendidikan, di samping itu pula pesantren masih mempunyai beberapa kelemahan yang menjadi penghambat, adapun kelemahan-kelemahan tersebut adalah:

a. Manajemen pengelolaan pondok pesantren

b. Kaderisasi pondok pesantren

c. Belum kuatnya budaya demokrasi dan disiplin, hal ini memang berkaitan erat dengan pondok pesantren yang independen

d. Kebersihan di lingkungan pesantren ${ }^{20}$.

Selain kelemahan-kelemahan di atas, yang menjadi penghambat yaitu:

a. Sebagian masyarakat memandang pesantren sebagai lembaga pendidikan kelas dua dan hanya belajar agama saja

b. Terbatasnya tenaga yang berkualitaas, khususnya mata pelajaran umum

c. Terbatasnya sarana yang memadai, baik sarana maupun ruang belajar

d. Masih dominannya sikap-sikap menerima apa adanya dikalangan sebagian pesantren

e. Sebagian pesantren masih bersifat ekslusif (Depag RI, 2003:19) ${ }^{21}$.

\footnotetext{
${ }^{19}$ Azyumardi, azra Pendidikan Islam Tradisi Dan Modernisasi Menuju milenium Baru (Ciputat: PT Logos Wacana ilmu. 2000)

${ }^{20}$ Maunah, Tradisi Intelektual... hal 49

${ }^{21}$ Ibid., hal 49-50
}

Apabila mencari pendidikan yang asli Indonesia dan berakar dalam masyarakat, tentu akan menempatkan pesantren di tangga teratas, namun ironisnya lembaga yang dianggap merakyat ini ternyata masih menyisihkan berbagai masalah dan diragukan kemampuannya dalam menjawab tantangan zaman, terutama ketika berhadapan dengan arus moden.

Seiring berjalannya waktu desakan dan hantaman justru masuk dari sisi yang lain, yaitu globalisasi. Banyak fenomena yang membuat lingkungan sekitar sangat merinding, fakta menggambarkan bahwa sudah terjadi pemelesetan tunas bangsa dari beberapa aspek lini kehidupan. Banyak generasi yang bercokol tidak sebagai generasi yang subur. Pun demikian banyak sekali komunitas terpelajar yang berujar; bahwa keharuman negeri itu bisa dilihat bagaimana putraputri bangsa ini.Pesantren Harus Akomodatif.

Adalah sebuah keniscayaan apabila perubahan zaman dinafikan, sebab perubahan itu justru akan menampilkan ciri kepribadian dan pencintraan pesantren itu dapat dipegang dengan kuat. Pesantren secara historis mampu menjadi benteng pertahanan, oleh KH. M. Sya'roni Ahmadi, beliau menjabarkan, bahwa urgensi pesantren sangat berperan aktif dalam kerangka memperjuangkan kemerdekaan sampai titik darah penghabisan. Kalau pesantren pada masa itu tidak memahami ahlussunnah wal jama'ah, tentu dapat kita gambarkan bagaimana agama yang akan dianut penduduk Indonesia secara mayoritas. Perlawanan ini tidaklah bermuara pada keterlibatan wawasan keagamaan saja, tetapi juga fisik dan mental untuk mengusir kaum penjajah yang selalu men-dzalimi bangsa Indonesia saat itu $^{22}$.

Bahkan sampai detik ini, pesantren tetap waspada dengan segala modernitas zaman, imperialisme budaya, deskontruksi moral, serta indikator lain yang begitu kuat merongrong dan mendesak budaya ketimuran secara hegemonik. Pesantren harus mampu menjadi muara peradilan agar tidak terseret kedalam arus itu,

${ }^{22}$ http: / / www.arwaniyyah.com / index. php?option $=$ com_content $\&$ view $=$ article $\& i d=62$ : pesantren-dan-tantangan-zaman\&catid $=40$ :artikellepas\&Itemid $=54$. diakses tgl 04-04-2012, jam 13.57 
yang senantiasa menjebaknya dalam kehampaan spiritual. Secara kontinyu pesantren harus membuktikan kesuksesanya untuk menjawab tantangan zaman. Mengenai bagaimana masa depan pesantren selanjutnya, tentu ia harus mampu menjadi lembaga yang tanggap akan segala persoalan yang pluralistik tanpa menghilangkan jati dirinya. Masalah tersebut tampaknya harus diambil langkah kongkrit dengan sikapnya yang akomodatif. Artinya pesantren tidak hanya merem terhadap kemajuan dan perkembangan tekhnologi modern. Ia harus lebih intens dengan mengkaji agama sebagai rujukan.

\section{Format Pendidikan Pesantren di Masa Modern}

Pesantren sesuai dengan ideologi developmentalism pemerintah orde baru, pembaruan pesantren pada masa ini mengarah pada pengembangan pandangan dunia dan subtansi pendidikan pesantren agar lebih responsif terhadap kebutuhan tantangan zaman. Selain itu juga, pembaruan pesantren ditekankan untuk fungsionalisasi pesantren sebagai salah satu pusat penting bagi pembangunan masyarakat secara keseluruhan. Dengan posisi dan kedudukan yang khas, pesantren diharapkan menjadi alternatif pembangunan yang berpusat pada masyarakat itu sendiri (peopole centered development) dan sekaligus sebagai pusat pengembangan pembangunan yang berorientasi pada nilai (value-oriented development $)^{23}$.

Azyumardi dalam bukunya menyimpulkan bahwasanya respon pesantren terhadap modernisasi pendidikan Islam dan perubahanperubahan sosial ekonomi yang berlangsung di masyarakat Indonesia sejak awal abad ini mencakup:

a. Pembaruan subtansi atau isi pendidikan Islam dan vocational

b. Pembaruan metodologi, seperti sistem klasikal, penjenjangan.

${ }^{23}$ Azyumardi, azra Pendidikan Islam Tradisi Dan Modernisasi Menuju milenium Baru (Ciputat: PT Logos Wacana ilmu. 2000), hal 105 c. Pembaruan kelembagaan, seperti kepemimpinan pesantren, diversifikasi lembaga pendidikan

d. Pembaruan fungsi, dari fungsi kependidikan untuk juga mencakup fungsi sosial-ekonomi ${ }^{24}$.

Dengan demikian jelaslah bahwa pesantren bukan hanya mampu bertahan. Tapi lebih dari itu, dengan penyesuaian, akomodasi dan konsesi yang diberikannya, pesantren pada gilirannya juga mampu mengembangkan diri, dan bahkan kembali menempatkan diri pada posisi yang penting dalam sistem pendidikan nasional Indonesia secara keseluruhan.

\section{RETHINKING PENGELOLAAN PESANTREN}

Pesantren dengan segala keunikan yang dimilikinya masih diharapkan menjadi penopang berkembangnya sistem pendidikan di Indonesia. keaslian dan kekhasan pesantren di samping sebagai khazanah tradisi budaya bangsa, juga merupakan kekautan penyangga pilar pendidikan untuk memunculkan pemimpin bangsa yang bermoral. Oleh sebab itu, arus globalisasi mengandaikan tuntutan profesionalisme dalam mengembangkan sumber daya manusia yang bermutu. Realitas inilah yang menuntut adanya manajemen pengelolaan lembaga pendidikan sesuai tuntatan zaman. Signifikansi professionalisme manajemen pendidikan menjadi sebuah keniscayaan di tengah dahsyatnya arus industrialisasi dan perkembangan teknologi modern. ${ }^{25}$

Dalam memahami gejala modernitas yang kian dinamis, pesantren sebagaimana diistilahkan Gus Dur 'sub kultur' memiliki dua tanggung jawab secara bersamaan, yaitu sebagai lembaga pendidikan agama Islam dan sebagai bagian integral masyarakat yang bertanggung jawab terhadap perubahan dan rekayasa sosial. ${ }^{26}$ Dalam kaitannya dengan respon keilmuan pesantren terhadap dinamika modernitas, setidaknya terdapat dua hal utama yang perlu diperhatikan.

\footnotetext{
${ }^{24}$ Ibid., hal 105

${ }^{25}$ Ibid., hal. 18

${ }^{26}$ Amin Haedari, dkk. 2004. Masa Depan Pesantren dalam Tantangan Modernitas dan Tantangan Kompleksitas Global. Jakarta: IRD Press., hal. 76
} 
Keduanya merupakan upaya kultural keilmuan pesantren, sehingga peradigma keilmuannya tetap menemukan relevansinya dengan perkembangan kontemporer. Pertama, keilmuan pesantren muncul sebagai upaya pencerahan bagi kelangsungan peradaban manusia di dunia. Kedua, peantren dipandang sebagai lembaga pendidikan, maka kurikulum pengajarannya setidaknya memiliki orientasi terhadap dinamika kekinian. ${ }^{27}$ Sebab inilah, perlu dibangun manajemen pesantren yang lebih memberdayakan sumber daya manusia agar siap menghadapi gejala modernitas.

Dari pemaparan di atas, dapat dianalisis beberapa faktor yang dapat menyebabkan pesantren sebagai lembaga pendidikan Islam masih memiliki kekurangan-kekurangan sebagai kelemahan yang harus dilengkapi.

Adapun kelemahan utama pesantren adalah masih minimnya pengelolaan atau manajemen pesantren, sebagaimana mengutip Sayid Agil Siraj dalam makalah Moh. Mujib Zunun menyebutkan bahwa ada tiga hal yang belum dikuatkan dalam pesantren.

Pertama, tamaddun yaitu memajukan pesantren. Banyak pesantren yang dikelola secara sederhana. Manajemen dan administrasinya masih bersifat kekeluargaan dan semuanya ditangani oleh kiainya. Dalam hal ini,pesantren perlu berbenah diri.

Kedua, tsaqafa yaitu bagaimana memberikan pencerahan kepada umatIslam agar kreatifproduktif, dengan tidak melupakan orisinalitas ajaran Islam. Salah satu contoh para santri masih setia dengan tradisi kepesantrenannya. Tetapi,mereka juga harus akrab dengan komputer dan berbagai ilmu pengetahuan serta sains modern lainnya.

Ketiga, hadharab, yaitu membangun budaya. Dalam hal ini, bagaimanabudaya kita dapat diwarnai oleh jiwa dan tradisi Islam. Di sini, pesantren diharapmampu mengembangkan dan mempengaruhi tradisi yang bersemangat Islam ditengah hembusan dan pengaruh dahsyat globalisasi yang berupayamenyeragamkan budaya melalui produk-produk teknologi ${ }^{28}$.

\footnotetext{
${ }^{27}$ Ibid., hal. 78-79

${ }^{28}$ http:/ / www.scribd.com/doc/25136062/MakalahManajemen-Pesantren, diakses tgl 05-04-2012, Pukul 12.02
}

Muhammad Khafifi dalam makalahnya memperkuat bahwa terdapa beberapa kelemahan yang masih ada di pondok pesantren, yaitu:

1. Pola kehidupannya mencontoh orang orang tasawuf, sehingga dalam pandangan kebanyakan orang, terlihat kumuh dan tidak terawat dengan baik serta kurang memperhatikan unsur keduniawian.

2. Kurangnya kemampuan dalam menalar, karena doktrin harus menghafal sehingga juga banyak yang kurang memahami pelajaran yang dihafalnya.

3. Kurang mengikuti perkembangan kitab-kitab terbaru dengan problematika yang terjadi di masyarakat.

4. Umumnya Pesantren tidak memiliki sarana dan prasarana yang memadai untuk menunjang kegiatan belajar mengajar.

5. Lebih dominant, karena memunculkan sikap otoriter, tidak proposional dalam pengelolaannya, tidak mudah menerima pembaharuan dari luar, dan terkesan eksklusif.

6. Tidak semua pondok pesantren memiliki kualitas yang sama didalam mendidik santrinya.

7. Fanatik terhadap salah satu pendapat (mdzhab) tertentu dengan tanpa mempelajari madzhab lainnya, sehingga kita tidak ada persoalan dalam masalah fiqih terjadi pertentangan dan saling menyalahkan ${ }^{29}$.

Namun demikian, pesantren akan tetap eksis sebagai lembaga pendidikan Islam yang mempunyai visi mencetak manusia-manusia unggul. Prinsip pesantren adalah al mubafadzab 'ala al qadim al shalih, wa al akbdzu bi al jadid al ashlah, yaitu tetap memegang tradisi yang positif, dan mengimbangi denganmengambil hal-hal baru yang positif. Persoalan-persoalan yang berpautan dengancivic values akan bisa dibenahi melalui prinsip-prinsip yang dipegang pesantren selama ini dan tentunya dengan perombakan yang efektif, berdaya guna, sertamampu memberikan kesejajaran sebagai umat manusia (al musarwah bain al nas).

WIB.

${ }^{29}$ Diambil dari makalah Muhammad Khafifi, Pembaharuan Sistem Pendidikan Pesantren 
Sebagai sebuah lembaga yang bergerak dalam bidang pendidikan dan sosial keagamaan, pengembangan pesantren harus terus didorong. Karena pengembangan pesantren tidak terlepas dari adanya kendala yang harusdihadapinya. Apalagi belakangan ini, dunia secara dinamis telah menunjukkan perkembangan dan perubahan secara cepat, yang tentunya, baik secara langsung maupun tidak langsung dapat berpengaruh terhadap dunia pesantren. Terdapat beberapa hal yang tengah dihadapi pesantren dalam melakukanpengembangannya, yaitu:

Pertama, image pesantren sebagai sebuah lembaga pendidikan yang tradisional, tidak modern, informal, dan bahkan teropinikan sebagai lembaga yang melahirkan terorisme, telah mempengaruhi pola pikir masyarakat untuk meninggalkan dunia pesantren. Hal tersebut merupakan sebuah tantangan yang harus dijawab sesegera mungkin oleh dunia pesantren dewasa ini.

Kedua, sarana dan prasarana penunjang yang terlihat masih kurangmemadai. Bukan saja dari segi infrastruktur bangunan yang harus segera dibenahi, melainkan terdapat pula yang masih kekurangan ruangan pondok (asrama) sebagai tempat menetapnya santri. Selama ini, kehidupan pondok pesantren yang penuh kesederhanaan dan kebersahajaannya tampak masih memerlukan tingkat penyadaran dalam melaksanakan pola hidup yang bersih dan sehat yang didorong oleh penataan dan penyediaan sarana dan prasarana yang layak dan memadai.

Ketiga, sumber daya manusia. Sekalipun sumber daya manusia dalam bidang keagamaan tidak dapat diragukan lagi, tetapi dalam rangka meningkatkan eksistensi dan peranan pondok pesantren dalam bidang kehidupan sosial masyarakat, diperlukan perhatian yang serius. Penyediaan dan peningkatan sumber daya manusia dalam bidang manajemen kelembagaan, serta bidang-bidang yang berkaitan dengan kehidupan sosial masyarakat, mesti menjadi pertimbangan pesantren.

Keempat, aksesibilitas dan networking. Peningkatan akses dan networking merupakan salah satu kebutuhan untuk pengembangan pesantren. Penguasaan akses dan networking dunia pesantren masih terlihat lemah, terutama sekali pesantren-pesantren yang berada di daerah pelosok dan kecil. Ketimpangan antarpesantren besar dan pesantren kecil begitu terlihat dengan jelas.

Kelima, manajemen kelembagaan. Manajemen merupakan unsur penting dalam pengelolaan pesantren. Pada saat ini masih terlihat bahwa pondok pesantren dikelola secara tradisional apalagi dalam penguasaan informasi dan teknologi yang masih belum optimal. Hal tersebut dapat dilihat dalam proses pendokumentasian (data base) santri dan alumni pondok pesantren yang masih kurang terstruktur.

Keenam, kemandirian ekonomi kelembagaan. Kebutuhan keuangan selalu menjadi kendala dalam melakukan aktivitas pesantren, baik yang berkaitan dengan kebutuhan pengembangan pesantren maupun dalam proses aktivitas keseharian pesantren. Tidak sedikit proses pembangunan pesantren berjalan dalam waktu lama yang hanya menunggu sumbangan atau donasi dari pihak luar, bahkan harus melakukan penggalangan dana di pinggir jalan

Ketujuh, kurikulum yang berorientasi life skills santri dan masyarakat. Pesantren masih berkonsentrasi pada peningkatan wawasan dan pengalaman keagamaan santri dan masyarakat. Apabila melihat tantangan ke depan yang semakin berat, peningkatan kapasitas santri dan masyarakat tidak hanya cukup dalam bidang keagamaan semata, tetapi harus ditunjang oleh kemampuan yang bersifat keahlian ${ }^{30}$.

\section{KESIMPULAN}

Pesantren sebagai lembaga pendidikan tertua yang masih bertahan hingga kini tentua saja harus sadar bahwa penggiatan diri yang hanya pada wilayah keagamaan tidak lagi memadai, maka dari itu pesantren harus proaktif dalam memberikan ruang bagi pembenahan dan pembaharuan sistem pendidikan pesantren dengan senantiasa harus selalu apresiatif sekaligus selektif dalam menyikapi dan merespon perkembangan dan pragmatisme budaya yang

\footnotetext{
${ }^{30}$ Makalah Moh. Mujib Zunun, diakses dari http://www.scribd.com/doc/25136062/MakalahManajemen-Pesantren, tgl 05-04-2012, pukul 12.30 WIB
} 
kian menggejala sehingga sangat diperlukan pembaharuan-pembaharuan yang harus dilakukan pesantren dalam menghadapi zaman modern, adapun pembaharuan-pembahuran tersebut bisa dilakukan pada:
a. Pembaharuan Metode pembelajaran
b. Pembaharuan Kurikulum
c. Pembaharuan Evaluasi
d. Pembaharuan Organisasi/ Manajemen

Tantangan tunggal pesantren di masa modern adalah adanya gesekan-gesekan globalisasi atau bisa disebut dengan tantangan modernisasi yang bersifat kompleks. Dalam menghadapi tantangan zaman, pesantren juga harus senantiasa memegang prinsip-prinsip pembaharuan yaitu: memiliki kebijaksanaan menurut ajaran Islam, memiliki kebebasan yang terpimpin, berkemampuan mengatur diri sendiri, memiliki rasa kebersamaan yang tinggi, menghormati orang tua dan guru, cinta kepada ilmu, mandiri, kesederhanaan.

\section{DAFTAR PUSTAKA}

Abdullah, Amin, 20077. Islamic Studies Dalam Paradigma Integrasi-Interkoneksi, Yogyakarta: Suka Press.

Assegaf, Rachman Abd. 2010. Pendidikan Islam Kontekstual, Yogyakarta: Pustaka Pelajar.

Azra, Azyumardi. 2000. Pendidikan Islam Tradisi Dan Modernisasi Menuju Milenium Baru, Ciputat: PT Logos Wacana Ilmu.
Daulay, Putra Haidar. 2004. Pendidikan Islam Dalam Sistem Pendidikan Nasional Di Indonesia, Jakarta: Prenada Media.

Khafifi, Muhammad. Pembaharuan Sistem Pendidikan Pesantren, makalah

Koncara, Lusiandani, Eka. Konsep Pembaharuan Dalam Islam, Purwakarta. makalab

Maunah. 2009. Tradisi Intelektual Santri Dalam Tantangan Dan Hambatan Pendidikan Pesantren Di Masa Depan, Yogyakarta: Teras 2009. Supervisi Pendidikan Islam Teori dan Praktek, Yogyakarta: Teras

Nahrawi, Amirudin. 2008. Pembaharuan Pendidikan Pesantren, Yogyakarta: Gama Media.

Rahardjo, Dawam. 1985. Pergulatan Dunia Pesantren Dari Bawah, Jakarta: P3M.

Roqib, Moh. 2009. Ilmu Pendidikan Islam, Yogyakarta: LkiS Yogyakarta.

Sanaky, AH. Hujair. 2003. Paradigma Pendidikan Islam Membangun Masyarakat Madani Indonesia, Yogyakarta: Safiria Insania Press.

http: / / www.arwaniyyah.com/index. php?option $=$ com_content\&view $=a$ rticle\&id $=62$ :pesantren-dan-tantanganzaman\&catid $=40$ :artikel-lepas\&Itemid $=54$. diakses tgl 04-04-2012, Pukul 13.57 WIB.

http://www.scribd.com/doc/25136062/ Makalah-Manajemen-Pesantren, diakses tgl 05-04-2012, Pukul 12.02 WIB.

http:/ / nursyam.sunan-ampel.ac.id/?p=952, diakses tgl 05-04-2012, Pukul 15.49 WIB. 